aid and informed consent tool for patients and surgeons - PubMed. Accessed July 21, 2021.

5. Nguyển Vạn Thiện, Thân Hà Ngọc Thể. Ảnh hưởng của suy yếu lên kết cục lâm sàng 30 ngày ở người cao tuổi trải qua phẫu thuât tiêu hoá. Published online 2019.

6. Chen CC-H, Lin M-T, Liang J-T, Chen C-M, Yen C-J, Huang G-H. Pre-surgical Geriatric Syndromes, Frailty, and Risks for Postoperative Delirium in Older Patients Undergoing
Gastrointestinal Surgery: Prevalence and Red Flags. J Gastrointest Surg. 2015;19(5):927-934.

7. Makary MA, Segev DL, Pronovost PJ, et al. Frailty as a Predictor of Surgical Outcomes in Older Patients. J Am Coll Surg. 2010;210(6):901-908.

8. Hewitt J, Long S, Carter B, Bach S, McCarthy K, Clegg A. The prevalence of frailty and its association with clinical outcomes in general surgery: a systematic review and meta-analysis. Age Ageing. 2018;47(6):793-800.

\title{
ĐặC ĐIỂM DỊCH TỄ HỌC LÂM SÀNG BỆNH TAY CHÂN MIỆNG Ở TRẺ EM TẠI BỆNH VIỆN ĐA KHOA XANH PÔN HÀ NộI
}

\section{TÓM TẮT}

Bệnh tay chân miệng là một bệnh truyền nhiễm cấp tính dễ gây thành dịch do virus ÉV71 và Coxsackie 16 gây nên. Bệnh hay gặp ở trẻ em và có hiệu quả điều trị tốt khi được phát hiện sớm, phân độ đúng và điều trị kịp thời khi trẻ chuyển độ nặng để giảm các biến chứng như bại não, viêm cớ tim, phù phổi cấp, thậm chí gây tử vong nhanh chóng nếu không được cấp cứu sớm. Mục tiêu: Mô tả đặc điểm lâm sàng, cận lâm sàng bệnh tay chân miệng tại khoa Nhi tổng hợp bệnh viện đa khoa Xanh Pôn. Đối tượng nghiên cứu: 80 bệnh nhân được chẩn đoán bệnh tay chân miệng được điều trị tại khoa Nhi tổng hợp bệnh viện đa khoa Xanh Pôn. Phương pháp: Nghiển cứu mô tả tiến cứu một loạt ca bệnh, từ 08/2020 đến 07/2021. Kết quả: Kết quả cho thấy tỷ lệ nam nhiều hơn nữ $2: 1$, tuổi trung bình $18 \pm 1,6$ tháng. Triệu chứng lâm sàng hay gặp nhất là sốt chiếm $100 \%, 53,8 \%$ sốt nhe $<38^{0} 5$ và $46,2 \%$ sốt cao $>38^{\circ} 5$ ban phỏng nước ớ da là $100 \%$, mức độ phát ban và loét miệng nặng chỉ có $11,3 \%$. $80 \%$ trẻ có tiếp xúc với nguồn lây bệnh. $78 / 80$ trẻ vào viên có dấu hiệu thân kinh, $100 \%$ trẻ có dấu hiệu giật mình, 69/80 trẻ có dấu hiệu tim mạch: $100 \%$ có mạch nhanh > 150 lần/ phút. 18/ 80 tré có mắc bệnh lý kèm theo. Trẻ nhập viện chủ yễu ở độ $2 b$ nhóm 1 là $58,8 \%$. Xét nghiệm: $28,8 \%$ trẻ có PCR EV71 (+). Bạch câu và CRP tăng ở nhóm tay chân miệng có mắc bệnh lý kèm theo. Kết luận: Bệnh tay chẩn miệng ở trẻ em là một bệnh dễ lây thành dịch. Triệu chứng hay gặp nhất của bệnh tay chân miệng là sốt nhẹ, triệu chứng xuất hiện đa dạng, có nốt ban phỏng nước bàn tay và bàn chân và vết loét ở miệng. Bệnh nhân cần nhập viện ở độ 2 . Virut EV71 là xét nghiệm có giá trị chẩn đoán xác định chỉ gặp ở $28,8 \%$. Chẩn đoán chính dựa vào triệu chứng lâm sàng đặc trưng của bệnh .

Tư khóa: bệnh tay chân miệng, EV71

\footnotetext{
*Trường Đại học Y Hà Nội

Chịu trách nhiệm chính: Soukhoumalay Phoumasay

Email: phousamay123@gmail.com

Ngày nhận bài: 3.8.2021

Ngày phản biện khoa học: 30.9.2021

Ngày duyệt bài: 6.10.2021
}

\section{SUMMARY \\ EPIDEMIOLOGY OF HAND - FOOT - MOUTH DISEASE IN CHILDREN AT SAINT PAUL GENERAL HOSPITAL}

Objective: To describe the clinical and laboratory characteristics of children with the hand - foot and mouth disease at Saint Paul hospital from August 2020 to July 2021. Subjects and method: Caseseries study. 80 patients diagnosed with hand, foot and mouth disease were treated at the General Pediatrics Department of Saint Paul General Hospital. Results: The male/female ratio is $2.1 / 1$. Average age is 1.8 - 1.6 years old. Fever is a common symptom accounting for $100 \%$. 53,8\% mild fever $<3805$ and $46,2 \%$ high fever > 3805 . Rash on the hands and feet: $100 \%$. The rate of patients with serious mouth ulcers and rash on hands and feet was $11.9 \%$. 80\% patients have contact with the source of infection. $78 / 80$ patients admitted to hospital have neurological signs. $100 \%$ patients show signs of startling, $69 / 80$ patients have signs of heart disease: $100 \%$ tarchycardia (over 150 beats per minute), 18/80 patients with other infection diseases. Patients at stage 2 b group 1: 58,8\%. PCR EV71 (+): $28 \%$. White blood cell and CRP increased in the group of hands, feet and mouth with comorbidities. Conclusion: Hand, foot and mouth disease in children is a contagious disease. It is a viral infection characterized by mild fever, a variety of symptoms, typical rash on hands and feet and mouth ulcers. Patient needs to be hospitalized at grade 2. EV71 virus is a test with definite diagnostic value found only in $28.8 \%$. The main diagnosis is based on the characteristic clinical symptoms of the disease.

Keywords; hand foot and mouth disease.

\section{I. ĐĂT VẤN ĐỀ}

Bệnh tay chân miệng (TCM) là một bệnh truyền nhiễm cấp tính dễ gây thành dịch, do virus Enterovirut 71 (EV71) và virut Coxsackie16 gây nên. Bệnh hay gặp nhất ở trẻ em dưới 5 tuổi ${ }^{1}$. Theo các kết quả nguyên cứu trên thế giới và Việt Nam, bệnh cần phát hiện sớm, phân độ 
đúng và điều trị kịp thời để tránh tử vong khi trẻ chuyển độ nặng gây các biến chứng bại não, viêm cơ tim, phù phổi cấp, thậm chí gây tử vong nhanh chóng 2,3,4.

Khoa nhi - bệnh viện đa khoa Xanh Pôn là trung tâm chăm sóc sức khỏe trẻ em Hà Nội, mỗi năm tiếp nhận nhiêu trẻ mắc bệnh TCM, số trẻ được chẩn đoán và điều trị bệnh tăng lên rõ rệt theo từng năm, để giúp cho các bác sĩ trong công tác khám chữa bệnh và đánh giá hiệu quả điều trị bệnh tốt hơn, chúng tôi tiến hành đề tài nghiên cứu với mục tiêu: Mô tả đặc điểm lâm sàng, cận lâm sàng bệnh tay chân miệng tại khoa Nhi tổng hợp bệnh viện đa khoa Xanh pôn. Với hy vọng kết quả nghiên cứu sẽ giúp ích cho các bác sĩ lâm sàng trong kinh nghiệm chẩn đoán bệnh kịp thời, nâng cao hiệu quả điều trị, tránh những biến chứng nặng và tử vong cho trẻ.

\section{II. ĐỐI TƯƠNGG VÀ PHƯƠNG PHÁP NGHIÊN CỨU}

2.1. Đối tượng nghiên cứu: 80 bệnh nhân được chẩn đoán bệnh tay chân miệng, được điều trị tại khoa Nhi tổng hợp bệnh viện đa khoa Xanh pôn từ tháng 8 năm 2020 đến tháng 7 năm 2021.

Tiêu chuẩn chọn bệnh nhân: bệnh nhân có biểu hiện sốt, mệt mỏi, đau họng. Sau vài ngày xuất hiện loét miệng, vết loét đỏ rải rác trong khoang miệng. Phát ban dạng phỏng nước ở lòng bàn tay, bàn chân, gổi và mông tồn tại trong vài ngày. EV71 có thể dương tính hoặc không (Phác đồ của BYT 2015)

2.2. Thiết kế nghiên cứu: nghiên cứu tiến cứu mô tả một loạt ca bệnh.

2.3 Cỡ mẫu: Chọn mẫu thuận tiện. Mỗi bệnh nhân được khai thác theo phiếu thu thập thồng tin có sẵn.

2.4 Các biến số nghiên cứu:

Đặc điểm lâm sàng: sốt, nôn, loét miệng, ban phỏng nước ở; bàn tay, bàn chân, da.

Phân độ: độ 1 , độ $2 a$, độ $2 b$ : nhóm $1,2 b$ nhóm 2 theo phác đồ của BYT 2015.

Biến chứng: Thần kinh; giật mình, kích thích, ngủ gà. Tim mạch: mạch nhanh > 150 lần / phút, vã mồ hôi, chi lạnh.

Bệnh lý kèm theo: viêm phế quản phổi, viêm tai giứa, viêm da mủ.

Đặc điểm cận lâm sàng: EV71, Công thức máu; Bạch cầu, $\mathrm{Hb}, \mathrm{CRP}$, các xét nghiệm được thực hiện ngay khi bệnh nhân vào viện và xét nghiệm tại Trung tâm xét nghiệm bệnh viện đa khoa Xanh pôn.

2.5. Phân tích và xử lý số liệu: Số liệu thu thập và xử lý phần mềm SPSS 20.0.

\section{KẾT QUẢ NGHIÊN CỨU}

Trong thời gian 1 năm, từ 8.2020 đến 7.2021 chúng tôi có 80 bệnh nhân đủ tiêu chuẩn chẩn đoán bị bệnh TCM điều trị tại khoa nhi Tổng hợp bệnh viện đa khoa Xanh pôn Hà nội.

\section{1 Đặc điểm lâm sàng của bệnh}

\subsubsection{Phân bố về giới}

Biểu đồ 1 : đặc điểm về giới

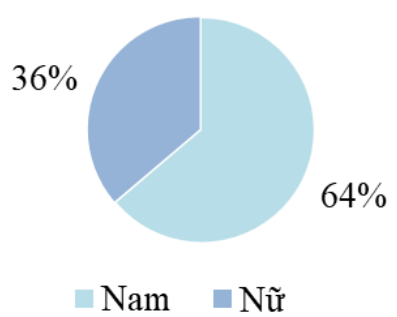

Nhận xét: Trẻ trai gặp nhiều hơn trẻ gái với tỷ lệ $2 / 1$.

\subsubsection{Phân bố về tuổi}

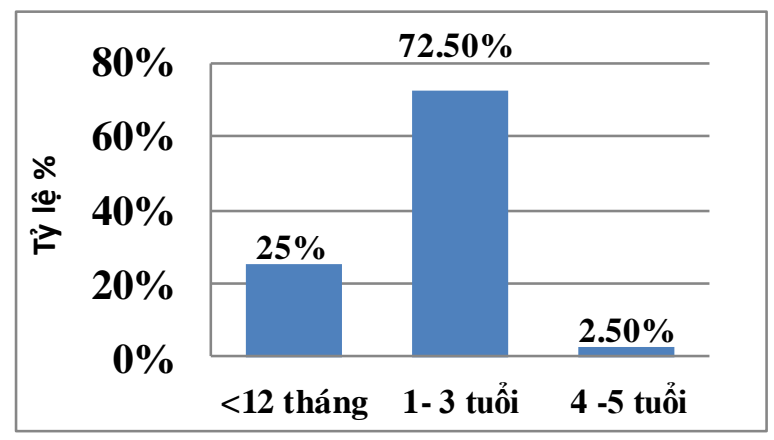

Biểu đồ 2. Phân bố bệnh nhân theo lứa tuổi

Nhận xét: Nhóm tuổi mắc cao nhất là 1-3 tuổi $(72,5 \%)$, tuổi trung bình $18 \pm 1,6$ tháng, nhỏ nhất 2 tháng và lớn nhất 5 tuổi.

\subsubsection{Phân bố triệu chứng lâm sàng của} bệnh TCM

Bảng 1. Triệu chứng lâm sàng khi được chẩn đoán

\begin{tabular}{|c|c|c|c|}
\hline Lâm sàng & Triệu chứng & $\mathbf{n}$ & $\begin{array}{l}\text { Tỷ lệ } \\
(\%)\end{array}$ \\
\hline \multirow{2}{*}{ Sốt } & $\begin{array}{c}\text { Sốt nhe } 37^{\circ} 5 \\
-38^{\circ} 5\end{array}$ & 43 & 53.8 \\
\hline & Sốt cao $\geq 38^{\circ} 5$ & 37 & 46.2 \\
\hline \multirow{2}{*}{$\begin{array}{l}\text { Phát ban phỏng } \\
\text { nước da ở bàn ta } \\
\text { và bàn chân và } \\
\text { loét miệng }\end{array}$} & Mức độ nặng & 9 & 11.3 \\
\hline & $\begin{array}{l}\text { Mức độ trung } \\
\text { bình }\end{array}$ & 71 & 88.7 \\
\hline \multicolumn{2}{|c|}{ Nôn } & 9 & 11.3 \\
\hline \multirow{2}{*}{$\begin{array}{l}\text { Tiếp xúc với } \\
\text { nguồn lây }\end{array}$} & Có & 64 & 80.0 \\
\hline & Không & 16 & 20.0 \\
\hline
\end{tabular}

Nhận xét: $100 \%$ bệnh nhân có sốt, sốt cao 
VIETNAM MEDICAL JOURNAL N²2 - OCTOBER - 2021

hoặc sốt nhẹ, 100\% bệnh nhân có triệu chứng phát ban da và mụn phỏng nước ở bàn tay và bàn chân, viêm loét miệng ở mức độ vừa và nặng. Triệu chứng nôn gặp ở 11,3\%bệnh nhân .

Bảng 2. Các triệu chứng nặng của bệnh chân tay miệng khi vào viện

\begin{tabular}{|c|c|c|}
\hline $\begin{array}{c}\text { Cơ quan tốn } \\
\text { thương }\end{array}$ & Triệu chứng & $\mathbf{n}$ \\
\hline \multirow{3}{*}{$\begin{array}{l}\text { Dấu hiệu } \\
\text { thân kinh } \\
(n=78)\end{array}$} & Giật mình & 78 \\
\hline & Vật vã, Kích thích & 70 \\
\hline & Run chi, đi loạng choạng & 4 \\
\hline \multirow{3}{*}{$\begin{array}{c}\text { Dấu hiệu tim } \\
\text { mạch } \\
n=69\end{array}$} & Mạch nhanh & 69 \\
\hline & $\begin{array}{c}\text { Mạch nhanh kịch phát } \\
>1801 / \text { phút }\end{array}$ & 3 \\
\hline & HA tăng & 15 \\
\hline
\end{tabular}

Nhânn xét: Triệu chứng thân kinh hay gặp nhất ở hâuu hết bệnh nhân, chủ yếu là dấu hiệu giật mình, dấu hiệu run chi, đi loạng choạng ít gặp hơn. Dấu hiệu mạch nhanh gặp $100 \%$, đặc biệt có 3 bệnh nhân có mạch nhanh kịch phát.

Bảng 3. Các bệnh kèm theo của bệnh chân tay miêng khi vào viênn.

\begin{tabular}{|c|c|c|}
\hline Bệnh kèm theo & $\mathbf{n}$ & Tỷ lệ \% \\
\hline Viêm phế quản phối & 11 & 60,0 \\
\hline Viêm tai giữa & 5 & 29,0 \\
\hline Viêm da mủ & 2 & 11,0 \\
\hline Tổng & $\mathbf{1 8}$ & $\mathbf{1 0 0}$ \\
\hline
\end{tabular}

Nhânn xét: trẻ bị TCM có kèm theo các bệnh nhiễm trùng khác như: viêm phế quản phổi gặp ở $60 \%$, viêm tai giữa, viêm da mủ ít gặp hơn. Các bệnh nhiễm trùng kèm theo làm cho tình trạng bệnh của trẻ nặng lên.

Bảng 4. Phân độ lâm sàng của bệnh nhân khi nhập viện

\begin{tabular}{|c|c|c|c|}
\hline \multicolumn{2}{|c|}{ Phân độ } & n & Tỷ lệ \% \\
\hline \multicolumn{2}{|c|}{ Đô̂ 1 } & 2 & 2,5 \\
\hline \multirow{3}{*}{ Độ 2 } & $2 a$ & 22 & $27,5 b$ \\
\cline { 2 - 4 } & 2b nhóm 1 & 47 & 58,8 \\
\cline { 2 - 4 } & 2b nhóm 2 & 9 & 11,2 \\
\hline Tống & & $\mathbf{8 0}$ & $\mathbf{1 0 0}$ \\
\hline
\end{tabular}

Nhận xét: $70 \%$ bệnh nhân bị bệnh giai đoạn 2b, 2b nhóm 1 chiếm 58,8\%. Có 2 bệnh nhân độ 1 vì kèm thêm bệnh khác khi nhập viện .

3.2 Đắc điểm của xét nghiệm bệnh TCM

Bảng 5. Đăc điểm xét nghiệm PCR EV71

\begin{tabular}{|c|c|c|}
\hline Giá trị PCR EV 71 & $\mathbf{n}$ & $\begin{array}{l}\text { Tỷ lệ } \\
(\mathbf{\%})\end{array}$ \\
\hline Dương tính & 23 & 28,8 \\
\hline Âm tính & 57 & 71,2 \\
\hline Tông số & $\mathbf{8 0}$ & $\mathbf{1 0 0}$ \\
\hline
\end{tabular}

Nhận xét; Xét nghiệm tìm nguyên nhân bằng PCR EV71 dương tính chỉ 28,8\%.

Bảng 6. Đặc điểm máu ngoại biên khi chẩn đoán

\begin{tabular}{|c|c|c|c|}
\hline Chỉ số & $\begin{array}{c}\text { Nhóm } \\
\text { TCM đơn } \\
\text { thuân }\end{array}$ & $\begin{array}{c}\text { Nhóm TCM cốnh kèm } \\
\text { bên } \\
\text { theo }\end{array}$ & P \\
\hline $\begin{array}{c}\text { Số lượng } \\
\text { bạch câu } \\
\left(1000 / \mathrm{mm}^{3}\right)\end{array}$ & $\begin{array}{c}10.832 \pm \\
3.342\end{array}$ & $\begin{array}{c}13.378 \pm \\
4.232\end{array}$ & $<0.05$ \\
\hline $\begin{array}{c}\text { Huyết sắc tố } \\
(\mathrm{g} / \mathrm{l})\end{array}$ & $\begin{array}{c}124.70 \pm \\
10.45\end{array}$ & $\begin{array}{c}126.77 \pm \\
9.48\end{array}$ & $>0.05$ \\
\hline CRP $(\mathrm{mg} / \mathrm{l})$ & $\begin{array}{c}11,66 \pm \\
15,37\end{array}$ & $\begin{array}{c}14,78 \pm \\
12,86\end{array}$ & $>0.05$ \\
\hline
\end{tabular}

Nhận xét: Số lượng BC trong nhóm TCM có nhiễm khuẩn tăng cao hơn nhóm bị TCM đơn thuân $(P<0,05)$. Lượng $\mathrm{Hb}, \mathrm{CRP}$ không có sự khác biệt giữa hai nhóm.

3.3 Ngày điêuu trị của bệnh nhân TCM

Bảng 7. Phân bố ngày đđiều trị trung bình trong bệnh lý TCM

\begin{tabular}{|c|c|c|c|}
\hline $\begin{array}{c}\text { Ngày } \\
\text { điều trị }\end{array}$ & $\begin{array}{c}\text { M } \pm \text { SD } \\
\text { (ngày) }\end{array}$ & Max & Min \\
\cline { 2 - 4 } & $5.7 \pm 2.1$ & 12 & 2 \\
\hline
\end{tabular}

Nhân xét: Thời gian nằm bệnh điều trị nội trú trung bình là $5.7 \pm 2.1$ ngày, ngày nằm điều trị ngắn nhất là 2 ngày, điêuu trị lâu nhất 12 ngày.

\section{BÀN LUÂN}

Trong một năm, có 80 bênh nhân nằm điều trị tại khoa nhi Tổng hợp bệnh viện đa khoa Xanh pôn được chẩn đoán bệnh TCM. Tuổi chẩn đoán chủ yểu ở nhóm trẻ nhỏ dưới 3 tuổi $(97,5 \%)$, tuổi trung bình là $18 \pm 1,6$ tháng. Trong đó trẻ trai gặp nhiều hơn trẻ gái tỷ lệ 2:1. Kết quả này cũng tương tự nghiên cứu của Trân Thị Trang Anh ${ }^{5}$ với tuổi mắc bệnh trung bình là $1,70 \pm 0,96$ tuổi, nhóm tuổi mắc cao nhất là 1-3 tuổi (68\%). Khi bệnh nhân nhập viện có 100 \% là dấu hiệu sốt, trong đó chủ yếu sốt nhẹ $<38^{\circ} 5$ là $53,8 \%$, sốt cao > 38 \% là 46,2\%. Tỷ lệ trẻ bị loét miệng tổn thương thường gặp ở vòm khẩu cái và/hoặc đâu lưỡi, dấu hiệu này gây cho bệnh nhân khó chịu, đau họng và chán ăn, kèm theo phát ban toàn thân, với biểu hiện râm rộ và lan nhanh chỉ có 9 bệnh nhân, phần lớn 88,7\% bệnh nhân biểu hiện ở mức độ trung bình và nhẹ kết quả nghiên cứu cũng tương tự các nghiên cứu khác. Nghiên cứu của Nguyễn Kim Thư 94,6\% bệnh nhi có loét miệng xuất hiện sớm trong 3 ngày đâu. Thời gian loét miệng trung bình là $2,1 \pm 1,39$ ngày. Kết quả này cũnng giống y văn và giống các nghiên cứu và nghiên cứu của Susheera Chatpoedprai ${ }^{7}$ tại Thái Lan 2008-2009. Biến chứng thần kinh hay gặp nhất 78/80 bệnh nhân, $100 \%$ biểu hiện ban đầu là giật mình, chỉ có 4 trường hợp vào viện có thêm dấu hiệu run chi và đi loạng choạng. Biến chứng tim mạch 69/80 bệnh nhân, có 3 bệnh nhân ngay khi vào 
viện, mạch nhanh liên tục trung bình trên 180 lần/ phút được theo dõi sát và chỉ có 15 bệnh nhân được đo huyết áp, nhận định kết quả tẳng nhẹ so với tuổi. Phân độ nặng của bệnh nhân khi nhập viện, chủ yếu là ở nhóm bệnh nhân độ $2 b$ nhóm 1 là 58,8\%, độ 2a là 17,5\%, độ 2b nhóm $211,2 \%$, độ 1 có $2,5 \%$, tỷ lệ này phù hợp với vai trò là một bệnh viện Nhi của Hà Nội, là nơi ban đâu chăm sóc trẻ em, do vậy phân lớn trẻ vào viện ở mức độ 2 trở lên, có 2 trường hợp độ 1, nhưng do có bệnh lý kèm theo suy dinh dưỡng và viêm phế quản. Bệnh TCM diễn biến thường nhẹ, chỉ có tỷ lệ nhỏ tiến triển nặng, những bệnh nhân này lại rất cân sự theo dõi chặt chẽ và xử trí kịp thời trong quá trình nằm viện để giảm biến chứng nặng. Trong nghiên cứu có nhiều trẻ chuyển độ nặng sau vài giờ, vài ngày nằm viện. Xét nghiểm tìm virut gây bệnh do EV71 được thực hiện 100\% các bệnh nhân bị CTM nhập viện, kết quả tìm được EV71 (+) chiếm $28,8 \%$, còn lại $71,2 \%$ âm tính hoặc không rõ nguyên nhân gấy bệnh. Cho nên các triệu chứng lâm sàng đặc trưng của bệnh có giá trị cao trong chẩn đoán bệnh. Nghiên cứu của Trân Thị Trang Anh ${ }^{5}$ ở bệnh viện nhi trung ương, có 817 trường hợp đước làm xét nghiệm PCR dịch ty. hâu tìm EV, dương tính chiếm $66,1 \%$, âm tính 33,9\%. Xét nghiệm bạch câu tăng trong trường hợp bênh nhân bị kèm bệnh nhiễm trùng như viêm phễ quản phổi, viêm da mủ. Xét nghiễ̂m công thức máu và CRP tăng ở tình trạng nhiễm khuẩn do các bệnh lý kèm theo, ở nhóm bệnh nhân TCM đơn thuân thì CRP và công thức bạch cầu bình thường, phù hợp với căn nguyên gây bệnh là do virut. Thời gian nằm viện ở nhóm bệnh nhân tay chân miệng trung bình là 5,7 ngày. Bệnh nhân phải điểu trị kéo dài do mắc các bệnh kèm theo hoặc chuyển độ nặng.

\section{KẾT LUẬN}

Bệnh tay chân miệng ở trẻ em là một bệnh dễ lây thành dịch, biểu hiện đa dạng, phân lớn là sốt nhẹ và phát ban phỏng nước ở bàn tay, bàn chân và loét miệng. Bệnh diễn biến thường nhẹ, nhưng cân phải vào viện điêuu trị và theo dõi chuyển độ khi có dấu hiệu biến chứng thân kinh và tim mạch. Xét nghiệm tìm EV71 chỉ gặp $28,8 \%$ cho nên triệu chứng lâm sàng đặc trưng vẫn có giá trị giúp chẩn đoán bệnh TCM.

\section{TÀl LIỆU THAM KHẢO}

1. Takahashi $S$, et al.(2018). Epidemic dynamics, interactions and predictability of enteroviruses associated with hand, foot and mouth disease in Japan. Journal of the Royal Society, Interface. 15(146),

2. Gonzalez G, et al.(2019). Enterovirus-Associated Hand-Foot and Mouth Disease and Neurological Complications in Japan and the Rest of the World. International journal of molecular sciences. 20(20),

3. Hsia SH, et al.(2020). Cardiopulmonary failure in children infected with Enterovirus A71. Journal of biomedical science. 27(1), 53.

4. Ngô Thị Hiếu Minh (2010). Nghiên cứu dịch tễ học, lâm sàng và cận lâm sàng bệnh tay chân miệng ở trẻ em. Luận văn Thạc sĩ Y học, Đại Học Y Hà Nổi.

5. Trân Thị Trang Anh (2013). Một số đặc điểm dịch tễ , lâm sàng, cận lâm sàng bệnh tạy chân miệng ở trẻ em tại khoa truyên nhiếm, bệnh viện nhi trung ương. Khóa luận tốt nghiệp bác sỹ y khoa, Khóa 2007 - 2013, Đại Học Y Hà Nội.

6. Nguyến Kim Thư (2016). Nghiên cứu đặc điểm lâm sàng, cận lâm sàng và căn nguyên vi rút gây bênh Tay Chân Miệng tại Việ̂t Nam. Luân án Tiến sỹ chuyên ngành Truyền nhiễm và các bệnh Nhiệt Đới. Trường Đại học Y Hà Nội.

7. Chatproedaprai S et al (2010). Clinical and Molecular Characterization of Hand-foot-and Mouth Disease in Thailand, 2008-2009. Japanese Journal Infectious Disease. 63(4), 229-33

\section{KẾT QUẢ ĐIỀU TRỊ UNG THƯ TUYẾN TIỀN LIỆT DI CĂN BẰNG LIẸUU PHÁP ỨC CHẾ ANDROGEN}

\section{TÓM TẮT.}

Mục tiêu: Đánh giá kết quả điều trị ung thư tiền liệt tuyến di căn bằng liệu pháp ức chế androgen. Đối tượng và phương pháp nghiên cứu: Nghiên cứu

*Trường Đại học Y Hà Nội

Chịu trách nhiệm chính: N̉guyễn Anh Tuấn

Email: dranhtuan2312@gmail.com

Ngày nhận bài: 2.8.2021

Ngày phản biện khoa học: 29.9.2021

Ngày duyệt bằi: 5.10 .2021

\section{Nguyễn Anh Tuấn', Vũ Hồng Thăng ${ }^{1}$}

mô tả cắt ngang trên 39 bệnh nhân ung thư tiền liệt tuyến giai đoạn di căn và được trị liệu bằng ức chế androgen (ADT) tai bênh viên $\mathrm{K}$ tữ tháng 1/2017 đến tháng 6/2021. Kết quả: Triệu chứng lâm sàng thường gặp tại thời điểm chẩn đoán: mất ngủ $(66,7 \%)$, tiểu khó $(69,2 \%)$, tiểu nhiều lần $(56,4 \%)$, đau xương $(59,0 \%)$. Có $71,8 \%$ bệnh nhân lựa chọn cắt tinh hoàn bằng ngoại khoa, 28,2\% cắt tinh hoàn bằng nội khoa. Sau 3 tháng điều trị, các triệu chứng thuyển giảm đáng kể: mất ngủ $(17,9 \%)$, tiểu khó $(20,5 \%)$, tiểu nhiều lần $(5,1 \%)$, đau xương $(28,2 \%)$. Thời gian sống thêm không tiến triển (PFS) trung bình là 